\title{
POTENSI MODAL SOSIAL MASYARAKAT DAERAH PASCA BENCANA DI KABUPATEN PONOROGO (INISIASI MODEL AGUNAN ALTERNATIF BERBASIS MODAL SOSIAL)
}

\author{
Ririn Tri Puspita Ningrum \\ Institut Agama Islam Negeri (IAIN) Kediri \\ Email: ririntripuspitaningrum@iainkediri.ac.id
}

\begin{abstract}
Natural disasters not only result in infrastructure losses, but also have an impact on education, social, cultural and economic. In the economic, special attention in efforts to revive the agricultural sector and UMKM of the affected communities was the focus of priority studies. This is because the two sectors have a significant role in the economy. This condition raised hopes for the banking and other financial institutions to make a positive contribution. However, in reality, the agriculture sector and UMKM have not been able to access some of the types of financing provided because there are several funds that require the availability of collateral that is material and difficult to fulfill. Therefore, it is necessary to have creative and innovative efforts based on the spirit of humanity related to alternative collateral models that are immaterial, that is based on social capital. Through a qualitative descriptive method and using a phenomenological approach, this research seeks to explore the potential power of the community (bottom-up process) in the economic development of areas affected by natural disasters. It is hoped that this research can produce datal information that is useful for implementing a participatory development system based on local strengths.
\end{abstract}

Keywords: Alternative Collateral, Financing, Social Capital, Economic Awakening, Agriculture, UMKM, Post-Disaster Areas

\begin{abstract}
Abstrak
Bencana alam selain berakibat pada kerugian infrastruktur, juga berdampak pada bidang pendidikan, sosial, budaya dan ekonomi. Di bidang ekonomi, perhatian khusus dalam upaya membangkitan kembali sektor pertanian dan UMKM masyarakat yang terdampak bencana menjadi fokus kajian prioritas. Hal ini dikarenakan dua sektor tersebut memiliki peran yang signifikan dalam perekonomian. Kondisi tersebut kemudian memunculkan harapan kepada dunia perbankan dan lembaga keuangan lainnya untuk memberikan kontribusi positif. Namun kenyataannya, sektor pertanian dan UMKM ternyata belum mampu mengakses beberapa jenis pembiyaan yang disediakan karena ada beberapa pembiayaan yang mengharuskan tersedianya jaminan/ agunan yang bersifat material dan sulit dipenuhi. Oleh karena itu perlu adanya usaha kreatif dan inovatif yang berlandaskan spirit kemanusiaan terkait model agunan alternatif bersifat immaterial, yakni berbasis pada modal sosial (capital social). Melalui metode deskriptif kualitatif dan menggunakan pendekatan fenomenologis, penelitian ini berupaya menelusuri potensi kekuatan masyarakat (bottom-up proses) dalam pembangunan ekonomi wilayah terdampak bencana alam. Diharapkan penelitian ini dapat menghasilkan data/ informasi yang berguna untuk mengimplementasikan sebuah sistem pembangunan yang partisipatif berbasis kekuatan lokal.
\end{abstract}

Website: http://jurnal.radenfatah..ac.id/index.php/ieconomics 
I-Economic: A Research Journal on Islamic Economics

ISSN 2548-5601, e-ISSN 2548-561X

Vol 6. No 1. Juni 2020

\section{Kata Kunci: Agunan Alternatif, Pembiayaan, Modal Sosial, Kebangkitan Ekonomi, Pertanian, UMKM, Daerah Pasca Bencana}

\section{PENDAHULUAN}

Bencana longsor yang terjadi di Desa Banaran Kecamatan Pulung Kabupaten Ponorogo pada awal April 2017 telah menjadi sorotan dan perhatian nasional. Terjadinya bencana alam tersebut selain berakibat pada kerugian infrastruktur, juga berdampak pada bidang pendidikan, sosial, budaya dan ekonomi. Di bidang ekonomi, kerugian terjadi pada sektor pertanian, perkebunan dan pertambangan, serta beberapa Usaha Mikro Kecil dan Menengah (UMKM) sehingga kini masyarakat masih meggantungkan hidupnya melalui bantuan Pemerintah dan masyarakat sekitar.1

Perhatian khusus dalam upaya membangkitan kembali sektor pertanian dan UMKM masyarakat yang terdampak bencana kiranya menjadi fokus kajian prioritas. Hal ini dikarenakan dua sektor tersebut memiliki peran yang signifikan dalam perekonomian. Pertanian merupakan sektor mata pencaharian mayoritas masyarakat, khususnya di Kabupaten Ponorogo karena sebagian merupakan wilayah agraris dan dataran tinggi. Demikian juga UMKM, meskipun belum menjadi sektor primadona namun UMKM dapat berperan memulihkan ekonomi daerah pasca bencana. UMKM dapat mendorong pertumbuhan ekonomi sehingga mampu menyerap tenaga kerja yang tidak dapat dilakukan oleh usaha-usaha besar.

Melihat peran sektor pertanian dan UMKM yang cukup signifikan, maka hal ini diharapkan turut memunculkan semangat bagi dunia perbankan dan lembaga pembiayaan lainnya untuk memberikan kontribusi dalam peningkatan produktifitas pada kedua sektor ini khususnya pada daerah pasca bencana. Namun kenyataannya, sektor pertanian dan UMKM masih dikonotasikan dengan sejumlah asumsi negatif, seperti tingginya resiko pengembalian, tidak efisiennya scale of business, lemahnya sistem manajemen dan administrasi, kurangnya pengalaman bisnis dan

1 Berdasarkan data yang diperoleh, terdapat 29 orang dan 36 unit rumah penduduk tertimbun tanah. Sekitar 4 hektar lahan pertanian milik 57 orang warga tertimbun longsor, padahal tanah tersebut sumber mata pencaharian warga (detiknews, Minggu 16 April 2017). Merujuk pada data statistik pada BPS Kabupaten Ponorogo (Pulung dalam Angka 2016), Desa Banaran memiliki lahan pertanian yang paling luas diantara 18 desa lainnya yang ada di Kecamatan Pulung Kabupaten Ponorogo yang mencapai hingga 2,795 ha dan lahan non pertanian pada peringkat kedua, sebesar 279 ha. Mata pencaharian warga Desa Banaran adalah sebagai petani (859 orang), buruh tani (121 orang), pengusaha industri (9 orang), buruh industri (11 orang), pengusaha bangunan ( 2 orang) dan buruh bangunan (71 orang). Hingga kini untuk sementara, masing-masing keluarga korban logsor mendapatkan santuanan sebesar Rp. 15 Juta dan jaminan hidup (jamdup) sebesar Rp. 900.000/ jiwa/ bulan.

Website: http://jurnal.radenfatah..ac.id/index.php/ieconomics 
penerapan teknologi dalam industri mikro kecil dan menengah, serta tidak adanya pemisahan antara modal usaha dengan kebutuhan pribadi. Hal ini terjadi karena umumnya sektor ini bersifat income gathering, yakni hanya terbatas pada keinginan untuk menaikkan pendapatan. Asumsi negatif itulah yang berdampak pada rendahnya akses pertanian dan UMKM terhadap pendanaan sektor perbankan (bankable).

Hingga saat ini, telah ada berbagai skim pembiayaan dengan bunga rendah (dari perbankan konvensional) atau sistem bagi hasil/ ujrah/ margin yang cenderung murah (dari perbankan syari'ah) atau dari lembaga pembiayaan lainnya untuk disalurkan pada sektor pertanian dan UMKM. Namun demikian, sektor pertanian dan UMKM ternyata belum mampu menjangkau dan mengakses beberapa jenis pembiyaan yang disediakan oleh lembaga keuangan tersebut. Hal ini disebabkan antara lain: skim pembiayaan yang telah ada saat ini masih terkonsentrasi pada pembiayaan untuk proses produksi, plafon pembiayaan yang masih relatif kecil, masih ada beberapa skim pembiayaan yang masih memerlukan jaminan/ agunan.

Sistem agunan merupakan syarat utama mendapatkan pembiayaan dari perbankan. Meskipun terdapat skim pembiayaan tanpa agunan, tetapi dirasa belum cukup membantu sektor pertanian dan UMKM karena pinjaman modal yang disediakan cenderung relatif kecil. Apalagi untuk masyarakat petani dan UMKM yang terdampak bencana, mereka tentunya telah mengalami banyak kerugian baik bersifat material maupun non material. Agunan yang dipersyaratkan tersebut tentunya memberatkan masyarakat dan sulit dipenuhi. Bantuan langsung dari Pemerintah dan Lembaga Non Government lainnya tentu belum sepenuhnya mampu mengembalikan keadaan normal masyarakat karena hal ini bersifat bertahap dan berkelanjutan.

Oleh karena itu, perlu adanya usaha kreatif dan inovatif yang berlandaskan spirit kemanusiaan dalam rangka membangkitkan sektor pertanian dan UMKM yang terdampak bencana agar tumbuh dan berkembang kembali, terutama terkait model agunan pada produk pembiayaan. Penelitian ini menfokuskan bahwa agunan/ jaminan alternatif yang dimaksud bukanlan agunan secara umun yang berbentuk materi, harta atau kebendaaan. Namun agunan alternati tersebut merupakan potensi dan kekayaan immaterial yang dimiliki oleh masyarkat, yakni berbasis pada modal sosial.

Modal sosial dewasa ini menjadi hal yang sangat dibutuhkan dalam menentukan keberhasilan pembangunan. Jika dilihat dari perkembanganya, keadaan masyarakat mengalami Website: http://jurnal.radenfatah..ac.id/index.php/ieconomics 
perubahan, kepercayaan mengalami pergeseran, kecurigaan, kebencian dan ketidakpercayaan menjadi atmosfer dalam masyarakat. Oleh karena itu, modal sosial juga akan menumbuhkan partisipasi masyarakat sehingga masyarakat lebih mandiri dalam memenuhi kebutuhannya sendiri tanpa harus menunggu uluran bantuan dari Pemerintah.

Di masyarakat Indonesia, modal sosial menjadi salah satu alternatif pembangunan dan pemberdayaan masyarakat, mengingat sebenarnya masyarakat Indonesia sangatlah komunal. Mereka memilki nilai-nilai yang sebenarnya sangat mendukung pengembangan dan penguatan modal sosial itu sendiri. Pasalnya, modal sosial memberikan pencerahan tentang makna kepercayaan, kebersamaan, toleransi dan partisipasi sebagai pilar pentingnya pembangunan masyarakat sekaligus pilar bagi demokrasi dan good governance (tata pemerintahan yang baik) yang sedang marak dipromosikan.

Implementasi otonomi daerah berdasarkan UU No. 32 Tahun 2004 tentang Pemerintahan Daerah, memberikan ruang dan peluang yang memadai bagi partisipasi aktif seluruh seluruh lapisan masyarakat dalam proses pembangunan daerah. Namun demikian, momentum ini belum sepenuhnya dapat dimanfaatkan dengan baik, mengingat masyarakat masih belum terbiasa untuk mengambil prakarsa dan menggunakan potensi yang dimilikinya bagi proses pembangunan. Masalah ini tentu tidak terlepas dari tradisi sosial politik masa lalu, di mana masyarakat cenderung dijadikan sebagai obyek pembangunan dan diposisikan secara marginal dalam konstelasi pembangunan bangsa dan negara. Situasi problematik ini sangat terasa terutama komunitas pedesaan.

Penelitian yang dilakukan ini, pada dasarnya merupakan salah satu upaya untuk menelusuri potensi kekuatan masyarkat (bottom-up proses) dalam pembangunan wilayah pedesaan khususnya daerah yang terdampak bencana alam untuk kemudian mengupayakan sebuah solusi permodalan dalam rangka membangkitkan kembali perekonomian masyarakat yang bergerak di sektor pertanian dan UMKM. Hanya masyarakat yang memiliki modal sosial yang dapat mendukung kebangkitan dan pengembangan ekonomi. Revitalisasi kebijakan dengan memanfaatkan dan mengembangkan modal sosial ini perlu dilakukan agar masyarakat mampu memperbaiki dan menggerakkan roda perekonomiannya kembali. Modal sosial inilah jika dapat dikelola dengan baik maka akan lebih mampu mengangkat dan memberdayakan masyarakat yang lemah (terdampak bencana). Oleh karena itu, melalui penelitian ini diharapkan dapat menghasilkan data/ 
informasi yang berguna bagi upaya-upaya penguatan masyarakat untuk bersama-sama dengan pemerintah desa dan lembaga-lembaga terkait lainnya dalam rangka mengimplementasikan sebuah sistem pembangunan dan pemerintahan yang partisipatif dan berbasis kekuatan lokal khususnya dalam hal pemberian modal/ pembiayaan pada masyarakat terdampak bencana. Berdasarkan latar belakang di atas, maka tujuan penelitian ini antara lain: (1) Untuk mengetahui potensi dan kekutan modal sosial yang dimiliki oleh masyarakat daerah pasca bencana di Kabupaten Ponorogo, (2) Untuk mengetahui strategi perumusan desain model agunan alternatif berbasis modal sosial sebagai upaya membangkitkan kembali sektor pertanian dan UMKM pada masyarakat daerah pasca bencana di Kabupaten Ponorogo.

\section{KERANGKA TEORI}

Teori yang digunakan oleh penulis dalam penelitian ini adalah menggunakan teori modal sosial (social capital) yang sudah banyak diperkenalkan oleh para ahli, antara lain:

Lyda Judson Hanifan menperkenalkan konsep modal sosial untuk pertama kalinya dalam tulisan berjudul "The Rural School Community Center". Ia mengungkapkan bahwa modal sosial bukanlah modal dalam arti biasa seperti harta kekayaan atau uang, tetapi lebih mengandung arti kiasan dan merupakan aset atau modal nyata yang penting dalam hidup masyarakat. Menurutnya, dalam modal sosial terdiri dari kemauan baik, rasa bersahabat, saling simpati, serta hubungan sosial dan kerjasama yang erat antara individu dan keluarga yang membentuk suatu kelompok sosial. 2

Bourdieu mendefinisikan modal sosial sebagai keseluruhan sumber daya baik yang aktual maupun yang potensial yang terkait dengan kepemilikan jaringan hubungan kelembagaan yang tetap dengan didasarkan pada saling kenal dan saling mengakui. Selanjutnya ia mengatakan bahwa modal sosial yang dimiliki oleh seorang anggota dari suatu kelompok tergantung dari sejauh mana kuantitas maupun kualitas jaringan hubungan yang diciptakan serta seberapa besar volume modal

2 L.J Hanifan. "The Rural School Community Centre", Annalis of The American Academy of Political and Social Science 67, 1916: 130

Website: http://jurnal.radenfatah..ac.id/index.php/ieconomics 
ekonomi, budaya dan sosial yang dimiliki oleh setiap orang yang ada dalam jaringan hubungannya.3

Robert Putnam dalam bukunya yang berjudul "Making Democracy Work: Civic Education: Civic Traditions in Modern Italy", ia mendefinisikan modal sosial sebagai "features of soial organization, such as networks, norm and trust, that facilitate coordination and cooperation for mutual benefit". Putman menganggap bahwa modal sosial sebagai seperangkat hubungan horizontal antar orang-orang. Maksudnya modal sosial terdiri dari "network of civic engagement" atau jaringan ketertarikan sosial yang diatur oleh norma-norma yang menentukan produktifitas suatu kelompok mayarakat atau komunitas. Jadi menurutnya, ada dua asumsi dasar dari modal sosial, yaitu adanya jaringan hubungan dengan norma-norma yang terkait, dan keduanya saling mendukung untuk mencapai keberhasilan di bidang ekonomi bagi orang-orang yang merupakan bagian dalam jaringan tersebut. 4

Francis Fukuyama dalam karyanya yang berjudul "Trust: The Social Virtues and The Creation of Prosperity", mengatakan bahwa kondisi kesejahteraan dan demokrasi serta daya saing suatu masyarakat dietentukan oleh tingkat kepercayaan antar sesama warganya. Ia berpendapat bahwa modal sosial akan menjadi semakin kuat apabila dalam suatu masyarakat berlaku norma saling balas membantu dan kerjasama yang solid melalui suatu ikatan jaringan hubungan kelembagaan sosial. Ia menganggap bahwa kepercayaan sangat berkaitan dengan akar budaya, terutama yang berkaitan dnegan etika dan moral yang berlaku. Karena itu ia berkesimpulan bahwa tingkat saling percaya suatu masyarakat tidak terlepas dari nilai-nilai budaya yang dimiliki oleh masyarakat tesebut.5

Di sisi lain, Robinson berpendapat bahwa modal sosial tidak lain adalah perasaan simpati dari seseorang atau suatu kelompok kepada seseorang atau kelompok lain. Perasaan simpati ini dapat berupa rasa kagum, perhatian, peduli, empati pengharagaan, rasa tanggung jawab atau kepercayaan terhadap suatu kelompok atau seseorang. Nilai lebih yang bersumber pada perasaan

\footnotetext{
3 Pierre Bourdieu, "The Form of Capita" dalam J. Richardons, Handbook of Theory and Research for The Sociology of Educations (Westport: Greenwood Press, 1986), 249.

4 Robert Putman, Robert Leonardi dan Rafella Nanetti, Making Democracy Work: Civic traditions in Modern Italy (Princeton: N.J: Princeton University Press, 1993), 36.

5 Francis Fukuyama, Trust: The Social Virtues and The Craetion of Prosperity (New York: The Free Press, 1995).
}

Website: http://jurnal.radenfatah..ac.id/index.php/ieconomics 
simpati ini menurut Robinson disebut sebagai barang sosio-emosional (socioemotional goods). Nilai yang berada di luar nilai simpati ini adalah nilai taransaksi ekonomi yang biasa, atau nilai instrinsik dari suatu benda. Sedangkan pemberian nilai pada sesuatu yang bersumber pada kondisi sosial-emosional tersebut dapat dikatakan sebagai nilai nominal yang tinggi rendahnya ditentukan oleh sikap pribadi. Pemberian nilai atau value attachment inilah dianggap Robinson sebagai faktor penentu modal sosial. 6

James C. Coleman dalam Hermawati melihat modal sosial dari sisi fungsinya. Dia menunjukkan bahwa struktur sosial dalam bentuk jaringan yang sifatnya lebih ketat dan relatif tertutup cenderung lebih efektif. 7 Jaringan komunitas yang dikembangkan oleh kelompokkelompok perantau di berbagai daerah lazimnya dibuat eksekutif, yang keanggotannya didasari oleh relasi kekerabatan dan kesamaan daerah, bahasa, etnis dan agama. Karena ketertutupannya itulah komunitas tersebut bisa survive dan menguasai jaringan perdagangan komoditas dan keterampilan tertentu di daerah perantauan. James Coleman medefinisikan modal sosial sebagai sesuatu yang memiliki dua ciri, yaitu merupakan aspek dari struktur sosial serta memfasilitasi tindakan individu dalam struktur sosial tersebut. Hal ini dapat diuraikan bahwa bentuk-bentuk modal sosial dapat berupa kewajiban dan harapan, potensi informasi, norma dan sanksi, hubungan otoritas serta organisasi sosial yang bisa digunakan secara tepat dan dapat menghasilkan kontrak sosial.

\section{METODE PENELITIAN}

Penelitian ini adalah penelitian lapangan (field research) dan merupakan jenis penelitian kualitatif untuk menghasilkan data deskriptif dari fenomena yang diamati 8, yaitu mengupayakan jawabanjawaban yang diperoleh melalui deskripsi komprehensif yang terkait dengan ungkapan, persepsi, tindakan, norma dasar dan kondisi sosial yang menerangkan tentang budaya dan nilai-nilai tradisional masyarakat daerah pasca bencana. Sedangkan pendekatan yang digunakan dalam

6 Lindon J, Robinson, Marcelo E. Siles, dan A. Alam Schmid, Social Capital and Proverty Reduction: Toward a Mature Paradigm (Departement of Agricultural economics, Michigan State University: Research Report, No. 13/2002), 5. IRE, 2002)

7 Hermawati, Mefi. Laporan Need Assesment Pengembangan Modal Sosial Masyarakat Adat (Yogyakarta:

8 Robert Bogdan \& Steven J. Taylor, Introduction to Qualitative Research Methods: A Phenomenological Aprroach to The Social Sciences (New York: John Wiley \& Sons, 1975), 42.

Website: http://jurnal.radenfatah..ac.id/index.php/ieconomics 
penelitian ini adalah menggunakan pendekatan fenomenologis yang bertujuan untuk memberikan deskripsi dan eksplanasi tentang fenomena yang dimaksud yaitu berkenaan dengan nilai-nilai, keyakinan, norma, simbol, bahasa dan praktek kehidupan sehari-hari pada masyarakat daerah pasca bencana. Lokasi yang dijadikan lokasi penelitian ini adalah di Desa Banaran Kecamatan Pulung Kabupaten Ponorogo. Melalui metode interaktif dan non interaktif, data yang diambil dalam penelitian ini adalah berupa budaya, nilai-nilai, kebiasaan yang tercermin dalam interaksi sosial pada masyarakat di Desa Banaran Kabupaten Ponorogo. Metode pengolahan data trediri dari pengecekan kembali, klasifikasi, verifikasi, analisa data.9 Sedangkan analisis data yang digunakan adalah melalui proses reduksi data (data reduction), penyajian data (data display) dan penarikan kesimpulan (conclution: drawing/verifying).10

\section{PEMBAHASAN}

\section{Karakteristik Geografis, Sosial, Ekonomi dan Kesejahteraan di Desa Banaran}

\section{Karakteristik Geografis}

Pulung merupakan Kecamatan yang terletak di wilayah timur Kabupaten Ponorogo yang terdiri atas 18 desa. Kecamatan Pulung memiliki total luas wilayah sebesar 12.755,00 Ha dan terletak didataran tinggi (pegunungan). Adapaun data lengkap masing-masing luas desa yang terdapat di Kecamatan Pulung terdapat pada tabel di bawah ini:

\section{Tabel 3.1. Luas Daerah Menurut Kelurahan/ Desa11 di Kecamatan Pulung KabupatenPonorogo}

\begin{tabular}{|r|l|r|r|}
\hline No & \multicolumn{1}{|c|}{ Kelurahan/ Desa } & Luas (Ha) & $\begin{array}{c}\text { Persentase terhadap } \\
\text { Luas Kecamatan (\%) }\end{array}$ \\
\hline 1 & Karangpatihan & 336,00 & 2,63 \\
\hline 2 & Tegalrejo & 249,00 & 1,95 \\
\hline 3 & Bedrug & 341,00 & 2,67 \\
\hline 4 & Wagirkidul & 522,00 & 4,09 \\
\hline 5 & Singgahan & 332,00 & 2,60 \\
\hline 6 & Patik & 242,00 & 1,90 \\
\hline 7 & Pulung & 331,00 & 2,60 \\
\hline
\end{tabular}

9 Lexy J. Moleong, Metodologi Penelitian Kualitatif (Bandung: Remaja Rosdakarya, 2007), 248.

10 Mathew B. Miles dan A. Michael Huberman, Analisis Data Kualitatif: Buku Sumber tentang Metodemetode Baru, terj Tjetjep Rohendi Rohidi (Jakarta: UI Press, 1992), 20.

11 Badan Pusat Statistik Kabupaten Ponorogo, Kecamatan Pulung dalam Angka: Tahun 2019 (Ponorogo: BPS Kabupaten Ponorogo, 2019)

Website: http://jurnal.radenfatah..ac.id/index.php/ieconomics 


\begin{tabular}{|c|l|r|r|}
\hline 8 & Pulungmerdiko & 157,00 & 1,23 \\
\hline 9 & Sidoharjo & $3.349,00$ & 26,26 \\
\hline 10 & Wotan & 386,00 & 3,03 \\
\hline 11 & Plunturan & 346,00 & 2,71 \\
\hline 12 & Pomahan & 494,00 & 3.87 \\
\hline 13 & Kesugihan & 288,00 & 2,26 \\
\hline 14 & Serag & 413,00 & 3,24 \\
\hline 15 & Wayang & 368,00 & 2,89 \\
\hline 16 & Munggung & 998,00 & 7,82 \\
\hline 17 & Bekiring & 529,00 & 4,15 \\
\hline 18 & Banaran & $3.074,00$ & 24,10 \\
\hline Jumlah & $\mathbf{1 2 . 7 5 5 , 0 0}$ & $\mathbf{1 0 0 , 0 0}$ \\
\hline
\end{tabular}

Desa Banaran, sebagai lokasi dan sumber penelitian ini merupakan desa yang memiliki luas daerah terbesar kedua di Kecamatan Pulung. Sebagai daerah pedesaan, Desa Banaran memiliki karakteristik sosial budaya serta norma masyarakat tentunya tidak terlepas dari pengaruh berbagai faktor seperti letak geografis, topografis serta sejarah terbangunnya masyarakat tersebut.

\section{Karakteristik Sosial}

Karakteristik sosial menekankan pada kehidupan sosial masyarakat yang mencakup aktivitas masyarakat dalam organisasi sosial kemasyarakatan, kelompok profesi, kelompok seni dan olah raga yang tumbuh dan berkembang di Desa Banaran. Terdapat beberapa kelompok masyarakat di Desa Banaran seperti Gapoktan, Koperasi Desa, BPD, PKK dan Arisan RT. Berbagai kegiatan selalu ruti dilakasanakan di dalam berbagai kelompok masyarakat tersebut.

Kelompok-kelompok yang tumbuh dan berkembang dalam suatu masyarakat menjadi wadah untuk berinteraksi bagi anggota masyarakat. Dalam pemahaman modal sosial, interaksi intensif antar individu dalam organisasi kemasyarakatan tersebut akan membangun modal sosial mengikat (bonding social capital). Semakin banyak waktu yang tercurah untuk membangun modal sosial dalam desa (bonding social capital) akan mengurangi kesempatan untuk membangun modal sosial dengan kelompok lain yaitu modal sosial menyambung (bridging social capital).

Website: http://jurnal.radenfatah..ac.id/index.php/ieconomics 
Tingginya intensitas pertemuan pada organisasi kemasyarakatan dapat mendorong terbangunnya interaksi yang intensif antar warga sehingga terjadi arus informasi yang lebih merata. Sealin itu, fungsi organisasi kemasyarkatan ini juga bersifat formal memperoleh pembinaan dari pemerintah kabupaten maupun provinsi.

Sealin itu, Desa Banaran tidak terlepas pula dari masalah kesejahteraan sosial (kemiskinan) masyarakatnya. Kemiskinan adalah fenomena yang terjadi di setiap wilayah. Peluang terjadinya kemiskinan dapat ditekan melalui modal sosial terutama adanya jaringan kerja yang kuat antar masyarakat. Terbangunnya jaringan kerja meningkatkan akses seseorang terhadap lembaga-lembaga keuangan baik formal maupun informal dan juga meningkatkan akses terhadap fasilitas pendidikan dan kesehatan yang akhirnya memutus rantai kemiskinan melalui peningkatan kualitas hidup. Bagaimanapun, jaringan kerja yang efektif akan mampu mengatasi kemiskinan apabila terbangun rasa percaya dan norma yang kuat.

Di bidang keamanan, di Desa Banaran tidak saja dilakukan oleh pemerintah tetapi juga dilakukan oleh warga desa sekitar. Keikutsertaan warga dalam menjaga keamanan di Banaran tersebut diharapkan dapat meningkatkan sistem kontrol terhadap seluruh aktivitas penduduk. Ada kecenderungan bahwa semakin tinggi itensitas penjagaan keamanan warga makan semakin rendah jumlah konflik yang terjadi.

\section{Karakeristik Ekonomi}

Letak geografis dan topografis wilayah berkaitan erat dengan mata pencaharian utama penduduk yang menetap di wilayah tersebut. Sebagian besar wilayah pedesaan di Kecamatan Pulung termasuk Desa Banaran terletak di dataran dengan topografis tinggi (pegunungan). Kesamaan lokasi pedesaan menyebabkan mata pencaharian masyarakat menjadi cenderung homogen sesuai dengan potensi sosial, ekonomi dan budaya wilayahnya. Mata pencaharian utama penduduk di Desa Banaran adalah petani, buruh tani dan pedagang.

Desa Banaran dikenal di Kabupaten Ponorogo dari sektor sektor pertanian dan perkebunannya. Hal ini karena kedua sektor tersebut merupakan sektor andalan bagi sebagian besar masyarakat di Desa Banaran. Hal ini disebabkan oleh (1) tingginya nilai sosial lahan yang membatasi pemilik lahan untuk menjual seluruh lahannya; (2)

Website: http://jurnal.radenfatah..ac.id/index.php/ieconomics 
keterikatan dan tanggung jawab yang tinggi terhadap keberadaan lahan yang berada di desa asal; dan (3) sanksi moral bagi individu yang menjual lahan warisan.

Bagi masyarakat di Desa Banaran, lahan pertanian merupakan warisan turun temurun yang harus dijaga. Selain itu, tingginya produktivitas lahan menjadi alasan lain yang menyebabkan masih berperannya sektor pertanian. Keberhasilan pembangunan pertanian dan perkebunan di Desa Banaran tidak terlepas dari peran Pemerintah serta tersedianya akses yang memudahkan proses pemasaran produk pertanian dan perkebunaan di Desa Banaran.

Sebagaian besar masyarkat di Desa Banaran masih menjadikan pertanian tanaman pangan (sayuran, buah dan biofarma) sebagai sumber mata pencaharian utama. Namun upaya penyerapan hasil-hasil pertanian di Banaran tergolong minim karena adalah rendahnya mutu produk dan kurangnya diversifikasi produk pertanian.

Norma dan budaya yang berkembang di sektor pertanian sangat terkait dengan nilai-nilai tradisional, sedangkan tuntutan masa sekarang harus sejalan dnegan nilainilai global yang relatif kurang menyerap nilai dan budaya lokal tersebut. Hal tersebut menjadi satu faktor penghambat berjalannya pengembangan kawasan pertanian sehingga mendorong terjadinya pengangguran dan mempercepat proses pemiskinan bagi kelompok-kelompok tertentu.

\section{Karakteristik Kesejahteraan}

Karakteristik kesejahteraan masyarakat diukur dari indikator tingkat pendapatan dan distribusi pendapatan di masing-masing wilayah penelitian. Masyarakat di Desa Banaran memiliki rataan pendapatan rendah. Salah satu faktor yang penyebabnya adalah kurang terkelolanya dengan baik sektor pertanian di Desa Banaran. Selain itu, sebagian besar petani di Banaran hanya mengusahakan tanaman pangan, hortikultura dan perkebunan secara tradisional. Di sisi lain, keterkaitan pertanian tanaman pangan dengan pariwisata relatif lemah akibat rendahnya kualitas produk pertanian yang dihasilkan masyarakat sehingga tidak mampu memenuhi standar kualitas yang disyaratkan oleh sektor pariwisata.

Website: http://jurnal.radenfatah..ac.id/index.php/ieconomics 


\section{A. Identifikasi Faktor dominan dan Keunggulan Modal Sosial di Desa Banaran (Trust, Norm, Hardworking, Networking)}

Tingginya stok modal sosial masyarakat dicirikan oleh adanya rasa percaya, tingginya kepadatan jaringan kerja, ikatan masyarakat yang kuat, pertukaran informasi, tingginya frekuensi kegiatan bersama, serta kepatuhan terhadap norma bersama untuk mewujudkan harapan bersama dan menghindari sifat oportunistik individu. Modal sosial mendorong terjadinya suatu proses pembangunan yang beretika dan bermoral yang bertujuan mencapai keseimbangan melalui distribusi hasil-hasil pembangunan yang merata dan berkelanjutan.

Saat ini di Indonesia, terdapat indikasi terjadinya pelemahan modal sosial masyarakat yang ditunjukkan oleh adanya peningkatan intensitas dan frekuensi kerusuhan antar warga masyarakat dalam satu wilayah baik antar etnis, suku, agama maupun antara masyarakat dan aparat pemerintahan, rendahnya partisipasi masyarakat terutama dalam pemeliharaan hasil-hasil pembangunan dan munculnya penolakan-penolakan terhadap kebijakan Pemerintah.

Membangun rasa percaya membutuhkan biaya dan waktu namun menghancurkannya dapat dilakukan dalam waktu yang singkat. Paling tidak ada dua cara yang dapat dilakukan untuk meningkatkan rasa percaya, yaitu: (1) membangun interaksi intensif yang berulang-ulang; dan (2) memahami dengan baik wakil-wakil (representasi) populasi di suatu wilayah, insentif yang mereka terima serta latar belakang populasi tersebut. Melemahnya rasa percaya masyarakat akan terjadi apabila kemauan baik untuk melakukan kegiatan bersama semakin menipis dan masyarakat memiliki kecenderungan bertindak asosial.

Melemahnya rasa percaya yang diikuti pula oleh melemahnya jaringan kerja ditunjukkan melalui penurunan partisipasi dalam aktivitas bersama, kesediaan saling tolong menolong serta berkurangnya peran pimpinan kelompok dan teman, terutama dalam penyebaran informasi. Selain itu, aturan-aturan yang rigid (kaku) dalam desa tidak mampu lagi menekan terjadinya pelanggaran dan pembangkangan terhadap aturan adat. Ketidaktaatan masyarakat terhadap aturan adat dan agama serta melemahnya kontrol 
masyarakat terhadap orang lain ditunjukkan oleh meningkatnya kasus kriminal dan konflik antar warga dan kelompok masyarakat.

Modal sosial di pedesaan merupakan salah satu sarana yang dapat digunakan oleh masyarakat pedesaan untuk meningkatkan peran mereka dalam berbagai kegiatan, khususnya di bidang pertanian dan perkebunan. Berbagai sarana modal sosial yang ada sebenarnya telah memberikan media bagi masyarakat desa untuk bergabung dalam rangka memikirkan peningkatan kesejahteraan.

Modal sosial dalam masyarakat hendaknya dipahami bahwa di dalam suatu komunitas terdapat keragaman (agama, budaya, kepentingan, status sosial, pendidikan, pendapatan, keahlian, gender) dari anggotanya, sehingga perlu adanya pemahaman yang mendalam terhadap keragaman tersebut. Sementara itu pemahaman nilai-nilai, norma menjadi hal yang penting. Unsur-unsur penting dalam modal sosial antara lain; rasa memiliki diantara anggota, jaringan kerjasama, rasa kepercayaan dan jaminan keamanan para anggota, saling memberi satu sama lain, saling berpartisipasi, dan bersikap.

\section{Karakteristik Rasa Percaya (Trust)}

Rasa percaya sosial merupakan bagian dari karakteristik individu, yang mencakup optimisme, keyakinan pada kerjasama, bahwasanya individu dapat menerima perbedaan dan hidup bersama dengan penuh kedamaian. Namun ada keraguan terhadap hubungan antara rasa percaya dan interaksi antar individu: penyebab ataukah akibat? Apakah rasa percaya yang tumbuh antar individu mendorong individu-individu tersebut untuk berinteraksi dan melakukan aktivitas bersama ataukah interaksi yang menyebabkan tumbuhnya rasa percaya? Ambiguitas tersebut tidak akan menimbulkan masalah bila kedua komponen memperoleh perhatian yang sebanding dalam upaya membangun modal sosial.

Hasil analisis menunjukkan bahwa masyarakat di Desa Banaran memiliki sikap kehati-hatian yang tinggi. Sikap ini ditunjukkan dengan tingginya rasa percaya masyarakat di Desa Banaran terhadap sesama warga desa dibandingkan dengan rasa percaya masyarakat dengan luar Desa Banaran. Sikap kehati-hatian dan rendahnya rasa percaya terhadap warga luar desa tersebut dapat mempengaruhi interaksi sosial yang seharusnya terbangun. Rasa percaya masyarakat desa ini menyebabkan mereka lebih

Website: http://jurnal.radenfatah..ac.id/index.php/ieconomics 
intens dengan warga sekitarnya sehingga mudah terbuka terhadap warga lain dan memudahkan akses satu sama lainnya. Keadaan ini mempertegas pendapat Fukuyama ${ }^{12}$ dan Levi ${ }^{13}$, yang menyatakan rasa percaya (trust) akan meningkatkan kekuatan dan daya saing ekonomi serta memungkinkan terjadinya proses pertukaran tanpa rasa takut akan terjadinya kecurangan

Di Desa Banaran terdapat pranata sosial yang hingga saat ini memiliki peran untuk menjaga adat di Desa Banaran (seperti adat rewang dan adat sambatan) dan mengikat kuat anggotanya melalui penerapan sanksi moral. Eksistensi pranata sosila ini tetap terjaga mengingat fungsi yang dijalankannya berhubungan erat dengan aktivitas keagamaan (seperti kenduren, tasyakuran, yasinan, tahlilan). Tingginya frekuensi aktivitas yang dilakukan menyebabkan tingginya intensitas interaksi antar individu dari desa yang sama dan mengurangi intensitas interaksi dengan desa lain. Hasil analisis menunjukkan bahwa rasa percaya antar warga sesama desa (thick trust) lebih tinggi dibandingkan dengan rasa percaya terhadap warga desa lain (thin trust).

Terdapat hubungan terbalik antara rasa percaya terhadap sesama anggota warga masyarakat (thick trust) dengan rasa percaya terhadap warga lain (thin trust) artinya semakin kuat rasa percaya terhadap sesama warga desa cenderung diikuti oleh melemahnya rasa percaya terhadap warga desa lain. Lemahnya rasa percaya terhadap warga lain (thin trust) harus diwaspadai mengingat dampaknya terhadap kerukunan antar warga, kelompok maupun golongan yang cenderung semakin heterogen di Banaran. Rendahnya thin trust akan berpengaruh terhadap interaksi antar kelompok masyarakat lokal dengan kelompok masyarakat pendatang maupun warga desa lain. Rendahnya thin trust cenderung akan mengurangi pula sikap keterbukaan (openness behaviour) yang merupakan salah satu komponen penting dalam pengembangan perekonomian di Banaran.

12 Fukuyama F, Trust: The Social Virtues and the Creation of Prosperity (New York: The Free Press, 13 Levi M, Social And Unsocial Capital: A Review Essay Of Robert Putnam's. Making Democracy Work, Politics and Society. 24(March) 1996.: 45-55.

Website: http://jurnal.radenfatah..ac.id/index.php/ieconomics 
Ada kemungkinan rendahnya thin trust masyarakat di Banaran disebabkan oleh rendahnya intensitas interaksi antar penduduk lokal dengan warga luar desa karena sesungguhnya masyarakat Banaran merupakan masyarakat yang sangat toleran, mudah beradaptasi dengan sistem yang terbuka. ${ }^{14}$

Rasa percaya bersifat dinamis yang dinamikanya dipengaruhi oleh faktor- faktor intensitas interaksi, kebudayaan, pengalaman dan institusi. ${ }^{15}$ Masyarakat mengakui bahwa rasa percaya mereka bersifat dinamis tidak statis.

Saling percaya diantara anggota organisasi sebagai dasar untuk menciptakan daya tanggap diantara anggota, dan juga dalam upaya untuk meningkatkan keuntungan bersama. Nilai-nilai kepercayaan dan daya tanggap di antara anggota akan menimbulkan kerjasama dan solidaritas. Nilai kepercayaan diantara anggota dan keuntungan bersama akan menciptakan jaringan dan kebijakan. Sementara daya tanggap dan keuntungan bersama akan menciptakan persaingan dan keberlangsungan usaha.

\section{Karakteristik Norma (Norm)}

Ketaatan pada norma-norma yang berlaku dalam organisasi masyarakat mendorong setiap anggota untuk memberikan kontribusi sesuai dengan ketetapan yang telah disepakati. Norma yang bersifat resiprokal menjadi alasan lain yang mendorong masyarakat untuk berpartisipasi dalam setiap kegiatan kemasyarakatan. Pengeluaran untuk kegiatan sosial merupakan indikator lain yang digunakan untuk memproksi modal sosial dalam penelitian ini..

Komponen modal sosial yang diamati dalam penelitian ini adalah norma saling bantu. Kehidupan sosial masyarakat tradisional di Banaran dibatasi oleh norma-norma yang tersusun dalam suatu aturan adat tidak tertulis. Misalnya, norma-norma kebersamaan pada adat rewang dan sambatan di Desa Banaran mengikat kuat sehingga mampu menjadi benteng pertahanan yang menahan masuknya berbagai nilai-nilai baru yang tidak dikehendaki bersama (contohnya: sifat individualis).

Press, 1995)

15 Azwar S, Sikap Manusia Teori dan Pengukurannya (Yogyakarta: Pustaka Pelajar. 2005)

Website: http://jurnal.radenfatah..ac.id/index.php/ieconomics 
Praktik saling bantu berarti saling bantu dalam menghadapi masalah yang bersifat material maupun non material. Kekuatan norma tersebut tentunya harus dilandasi oleh sikap saling percaya dan bersifat resiprokal. Rasa percaya tidak saja memelihara keberlangsungan norma-norma yang mengandung nilai kearifan namun juga mendasari keputusan seseorang untuk bergabung dalam suatu kelompok maupun sebaliknya memisahkan diri dari kelompok yang telah diikuti sebelumnya.

Suatu kelompok atau komunitas yang masing-masing anggotanya memiliki rasa percaya yang tinggi dikatakan kaya akan modal sosial. Ahli sosiologi, antropologi dan ilmu politik menyatakan bahwa rasa percaya memiliki peran penting berkaitan dengan pelaksanaan aktivitas bersama (colective action). Kuat lemahnya modal sosial dalam suatu masyarakat dapat diukur melalui tinggi rendahnya tingkat rasa percaya antar masyarakat yang juga tergambarkan melalui partisipasi masing-masing anggota dalam aktivitas bersama dan intensitas kegiatan tersebut. Oleh karena itu, seringkali pula dikatakan bahwa rasa percaya atau modal sosial adalah barang publik (public good), setiap anggota memiliki kesempatan memanfaatkannya namun seringkali merasa tidak berkewajiban untuk memeliharanya. Salah satu upaya untuk menjaga modal sosial adalah melalui sikap tolong menolong antar anggota masyarakat.

Semua masyarakat yang memiliki rasa percaya tinggi hampir semuanya bersedia memberikan bantuan namun hanya. Sebaliknya, ada sebagian kecil masyarakat yang memiliki kepercayaan rendah atau kelompok masyarakat yang selalu berhati-hati menyatakan jarang bahkan tidak pernah membantu orang lain. Hal ini menunjukkan bahwa secara tidak langsung, masyarakat di Banaran selalu berupaya untuk menjaga hubungannya dengan pihak lain dengan cara selalu bersikap saling bantu membantu. Menjaga hubungan sosial tersebut dalam pengertian lain berarti menjaga modal sosial dalam masyarakat. Sikap hati-hati yang mereka miliki tidak mengurangi sikap saling bantu. Sikap tolong-menolong masyarakat di Banaran lebih bersifat resiprokal yang terpelihara karena adanya kepercayaan terhadap norma yang berlaku di masyarakat.

Hal tersebut sesuai dengan teori tradisional, kelompok masyarkat merupakan organisasi atau kelompok yang memiliki sifat yang ada di mana-mana (ubiquitous) karena 
kecenderungan manusia adalah bergabung dan berasosiasi. Mosca dalam Olson 16 menyatakan bahwa insting manusia adalah bergelombol bersama (herding together) dan bersaing dengan kelompok yang lain (fighting with other herds). Sedangkan posisi moral adalah mampu meningkatakan insting suatu masyarakat tertentu.

Setiap individu dalam suatu kelompok masyarakat akan berupaya mencapai tujuan bersama hanya jika indivisu tersbut juga dapat memperoleh keuntungan. Hal ini berdasarkan anggapan bahwa kelompok individu dengan kepentingan bersama (common interest), yang salah satunya adalah untuk mencapai tujuan-tujuan ekonomi, akan berupaya mengembangan tujuan bersamam tersebut. Setiap individu diharapkan dapat mendahulukan kepentingan bersama daibandingakan kepentingan individu. Hal ini dapat diasumsian bahawa setiap individu dalam suatu kelompok masyarakat akan bertindak di luar keinginan pribadinya sesuai dengan kesepakatan yang telah ditetapakan oleh masyarakat. Oleh karena itu, sangat dibutuhkannay adanay norma yang mampu mengatur peran dan perilaku individu dalam suatu masyarkat sehingga mencapaiaan kepentingan individu dapat dicapai secara proporsional tanpa mengenyampinkan kepentungan masyarakat.

Noma merupakan nilai yang mengatur perilaku individu dalam suatu kelompok masyarakat. Fukuyama17 menyatakan bahwa modal sosial sebagai norma informal yang bersifat insatn dapat mendukung mengembangakan kerjasama antar individu. Dengan norma sosial selain dapat menentukan perilaku bersama dalam suatu kelompok individu, juga dipahami sebagai prinsip keadilan yang mengarahkan individu untuk berperilaku yang tidak mementingkan kepentingan sendiri.

\section{Karakteristik Pekerja Keras (Hardworking)}

Sebagai keunggulan dalam pengelolaan modal sosial di Desa Banaran adalah frekuensi pertemuan dari para anggota cenderung rutin, yaitu setiap sebulan sekali, selapanan (35 hari sekali) dan tiga bulan sekali. Tingkat kehadiran masyarakat desa juga sangat tinggi, setiap pertemuan rata-rata dihadiri oleh 40 orang, dengan jumlah terbesar yang hadir pada modal sosial Gapoktan, Koperasi Desa, BPD, PKK dan Arisan RT.

16 Mosca dalam Olson M, The Rise and Decline of Nation (New Haven: Yale University Press, 1982).

17 Francis Fukuyama, Trust: The Social Virtues and TheCraetion of Prosperity (New York: The Free Press, 1995).

Website: http://jurnal.radenfatah..ac.id/index.php/ieconomics 
Hasil penelitian menunjukkan bahwa rata-rata frekuensi pertemuan warga Desa Banaran adalah satu minggu sekali. Frekuensi pertemuan yang cenderung rutin ini mengindikasikan bahwa modal sosial yang ada di Desa Banaran ini sebenarnya merupakan modal yang kuat bagi masyarakat pedesaan sebagai bentuk kepercayaan dan tingginya hardworking diantara warga desa.

Modal sosial dalam suatu negara merupakan penentu utama dalam komposisi dan pertumbuhan dari output dan ekspor negara. Sebagai contoh: kesehatan dan makanan yang cukup akan dapat meningkatkan produktivitas pekerja, masyarakat pedesaan. Dalam bidang pertanian terbukti bahwa terdapat dampak positif modal sosial terhadap produktivitas diantara para petani yang menggunakan teknologi modern, dibanding dengan penggunaan metode tradisional.

\section{Karakteristik Jaringan Kerja (Networking)}

Komponen lain dari modal sosial yang diamati dalam penelitian ini adalah jaringan kerja formal dan informal. Jaringan kerja informal ditunjukkan oleh jumlah teman dekat yang dipercayai untuk berkeluh kesah maupun dimintai pendapat dan pandangannya mengenai berbagai hal. Setiap individu di pedesaaan memiliki jumlah teman yang lebih sedikit. Jumlah teman dapat menjadi jaringan sosial yang memberi jaminan bahwa ada orang lain yang setiap saat bersedia membantu.

Jaringan kerja formal merupakan jaringan kerja dalam organisasi. Ketergantungan masyarakat di Banaran terhadap satu organisasi, nampak dalam kehidupan bermasyarakatnya yang ditunjukkan oleh beragam jenis organisasi terpenting bagi kehidupannya. Sehingga, sebagian besar masyarakat perdesaan menyatakan bahwa organisasi tradisional merupakan kelompok terpenting yang berkaitan langsung dengan tingkat kesejahteraannya.

Hal tersebut sesuai dengan teori bahwasanya jaringan kerja pada dasarnya menekankan pada pentingnya organisasi vertikal dan horisontal antar manusia serta hubungan inter dan intra organisasi tersebut. Granovetter ${ }^{18}$ menyatakan bahwa ikatan kuat antar masyarakat (strong ties) sangat diperlukan untuk memberikan identitas pada

18 Granovetter MS, The Strenght of Weak Ties (American Journal of Sociology, 78, 1360-80, 1973)

Website: http://jurnal.radenfatah..ac.id/index.php/ieconomics 
keluarga dan masyarakat serta tujuan bersama di anatara mereka. Pandangan ini juga menganggap bahwa lemahnya ikatan antar masyarakat (weak ties) yang menghubungkan berbagai organisasi sosial akan memicu ikatan horisontal yang sangat kuat (strong ties) sehingga menjadi dasar untuk mewujudkan keinginan kelompok yang terbatas.

Modal sosial adalah suatu keadaan dimana individu-individu dapat menggunakan keanggotaannya dalam suatu kelompok untuk memperoleh manfaat. Modal sosial tidak dapat dinilai dan dievaluasi tanpa pengetahuan mengenai dimana dan bagaimana individu tersebut berada, karena interaksi sosial tergantung dari struktur jaringan kerja dan struktur masyarakat yang ada di dalamnya. $\operatorname{Coleman}^{19}$, berpendapat bahwa kepadatan jaringan kerja sosial akan meningkatkan efisiensi penguatan perilaku kerjasama dalam suatu organisasi. Menurutnya, modal sosial adalah jumlah dari "relational capital" yang dimiliki beberapa individu dan dibangun berdasarkan norma resiprositas. Hubungan sosial yang terbangun dalam suatu penutupan (closure) struktur sosial, tidak hanya penting untuk membangun norma yang efektif tetapi juga membangun kepercayaan. Hal ini disebabkan karena penutupan jaringan kerja (network closure) tersebut menghasilkan eksternalitas ekonomi positif melalui proses fasilitasi terhadap aksi bersama (collective action).

Woolcock ${ }^{20}$ membedakan secara tegas antara modal sosial yang mengikat, menyambung dan mengait (bonding, bridging dan linking social capital). Menurutnya, modal sosial yang bersifat mengikat (bonding) umumnya berasal dari ikatan kekeluargaan, kehidupan bertetangga dan sahabat. Anggota dalam kelompok ini umumnya berinteraksi secara intensif, face-to-face dan saling mendukung. Modal sosial yang bersifat menyambung (bridging) terbentuk dari interaksi antar kelompok dalam suatu wilayah dengan frekuensi yang relatif lebih rendah seperti kelompok agama, etnis, atau tingkat pendapatan tertentu. Sedangkan modal sosial yang bersifat mengait (linking) umumnya terbentuk dari hubungan formal antar berbagai pihak seperti lembaga politik, 94, 1988)

${ }_{19}$ Coleman JS, Social Capital in The Creation of Human Capital (American Journal of Sociology, Vol.

20 Woolcock, Social Capital and Economic Development: Toward a Theoritical Synthesis and Policy Framwork (Netherland: Kluwe Academic Publisher, 1998)

Website: http://jurnal.radenfatah..ac.id/index.php/ieconomics 
I-Economic: A Research Journal on Islamic Economics

ISSN 2548-5601, e-ISSN 2548-561X

Vol 6. No 1. Juni 2020

bank, klinik kesehatan, sekolah, bisnis/ perdagangan, pertanian, kepariwisataan dan sebagainya.

\section{B. Revitalisasi Bisnis Keuangan Dan Kebangkitan Ekonomi Melalui Agunan Alternatif (Pebiayaan Berbasis Modal Sosial)}

\section{Dasar Penentuan Strategi Pembentukan Agunan Alternatif (Pembiayaan Berbasis Modal Sosial)}

Pola pembiayaan berbasis modal sosial bagi masyarakat tertentu yang disediakan baik oleh lembaga keuangan formal dan non formal, lembaga keuangan bank dan non bank, serta lembaga keuangan umat (lembaga zakat dan wakaf) sangat dibutuhkan bagi masyarakat kecil. Apalagi pola pembiayaan tersebut memang menyediakan akses permodalan atau pembiayaan bagi masyarakat kecil yang belum memiliki akses pada produk-produk pembiayaan umum yang disediakan oleh lembaga keuangan formal.

Pembiayaan yang pro pada masyarakat kecil hendaknya tidak berdasarkan pada persyaratan tersedianya jaminan (agunan) yang bersifat material, namun lebih dari itu karena mengarah pada potensi yang ada dalam masyarakat itu sendiri yang bersifat immaterial (modal sosial). Dengan adanya modal sosial tersebut pihak pemberi pembiayaan/ permodalan (shahibul maal) dapat menjadikannya sebagai bagaian penilaian dari implementasi prinsip kehati-hatian atas pembiayaan/ permodalan yang akan disalurkan kepada masyarakat tersebut.

Pola pembiayaan dengan sistem penjaminan modal sosial tersebut lebih dilatarbelakangi oleh kemiskinan dan kesenjangan ekonomi yang mengakibatkan sebagian kelompok masyarakat terutama yang berada di pelosok pedesaan tidak dapat mengakses layanan perbankan dalam kaitannya dengan pengajuan pinjaman modal usaha. Berdasarkan latar belakang tersebut, lembaga keuangan baik bank dan non bank harusnya hadir ke tengahtengah kelompok masyarakat marginal untuk memberikan layanan dan akses bantuan.

Implementasi model pembiayaan jenis ini tentu sangat membutuhkan peran aktif seluruh elemen masyarakat melalui pemberdayaan ekonomi umat. Salah satu elemen masyarakat tersebut adalah organisasi-organisasi yang ada di pedesaaan. Jika dilihat organisasi-organisasi tersebut baik yang bergerak di bidang pertanian, ekonomi, sosial dan keagamaan banyak tersebar di berbagai pedesaaan dengan sistem kontrol dan pengawasan Pemerintah Desa. Hal ini menunjukkan adanya potensi yang besar untuk pemberdayaan umat

Website: http://jurnal.radenfatah..ac.id/index.php/ieconomics 
I-Economic: A Research Journal on Islamic Economics

ISSN 2548-5601, e-ISSN 2548-561X

Vol 6. No 1. Juni 2020

guna mengentaskan kemiskinan dan mengikis kesenjangan ekonomi dalam masyarakat melalui pranata-pranata desa sebagia wadah dari implmetasi modal sosial yang ada di masyarakat pedesaaan.

\section{Strategi Perumusan Desain Model Agunan Alternatif (Pembiayaan Berbasis Modal Sosial)}

Untuk menjalankan kegiatan usahanya, setiap lembaga baik lembaga keuangan formal dan non formal serta lembaga keuangan bank dan non bank, pasti berorientasi pada laba. Semakin besar laba, semakin menarik bagi investor untuk berinvestasi atau menanamkan modal di dalamnya dengan harapan mendapatkan pengembalian yang besar dari laba tersebut. Sedikit berbeda dengan pola pembiyaan jenis ini, karena permodalan lembaga keuangan jenis ini bukanlah dari hasil investasi melainkan donasi. Donasi tidak hanya disalurkan pada lembaga zakat atau lembaga wakaf, namun lebih dari itu donasi pada lembaga manapun baik perusahaan maupun perorangan yang memiliki kelebihan dana, kepedulian, dan komitmen untuk membantu mengentaskan kemiskinan serta meningkatkan taraf hidup masyarakat marginal yang belum tersentuh oleh layanan produk-produk pembiayaan yang umumnya terdapat pada perbankan formal.

Dilihat dari sumber modalnya, orientasi jenis pembiayaan dengan model berbasis modal sosial tersebut cenderung lebih banyak bersifat sosial dan sedikit untuk pencapaian laba. Hal ini ditunjukkan dengan rendahnya imbal hasil pinjaman yang dibebankan kepada nasabah. Selain itu pembiayaan melalui lembaga-lembaga tersebut disalurkan tanpa agunan yang bersifat material dan didasarkan pada prinsip syariah.

Model pembiayaan jenis ini memiliki keunikan tersendiri yang membedakannya dari produk-produk pembiayaan pada bank secara umum. Keunikan ini sekaligus menjadi karakteristik atau ciri khasnya yang membedakan dengan produk pembiayaan perbankan lainnya. Adapun karakteristiknya antara lain: (1) Nasabah hanya terbatas pada masyarakat pedesaan atau pelosok, (2) Pembiayaan diberikan kepada kelompok, bukan perorangan, (3) Sumber modal berupa donasi, bukan investasi, (4) Pembiayaan bersifat produktif, (5) Adanya pembinaan usaha bagi nasabah, (6) Margin bagi hasil yang sangat rendah, (7) Nasabah tidak dibatasi oleh agama.

Website: http://jurnal.radenfatah..ac.id/index.php/ieconomics 
I-Economic: A Research Journal on Islamic Economics

ISSN 2548-5601, e-ISSN 2548-561X

Vol 6. No 1. Juni 2020

\section{SIMPULAN}

Mengacu pada fokus penelitian tentang potensi modal sosial pada daerah pasca bencana di Desa Banaran Kecamatan Pulung Kabupaten Kediri, maka kesimpulan yang dapat ditarik dalam penelitian ini antara lain:

Potensi dan kekuatan modal sosial yang dimiliki oleh masyarakat daerah di Desa Banaran Kecamatan Pulung Kabupaten Ponorogo terdiri dapat dilihat dari karekateristik trust, norm, hardworking, networking. Pertama, terkait dengan kekuatan rasa percaya (trust), di Desa Banaran menunjukkan bahawa rasa percaya antar sesama desa (thick trust) lebih tinggi dibandingkan dengan rasa percaya terhadap desa lain (thin trust). Saling percaya diantara warga satu desa dan antar anggota organisasi sebagai dasar untuk menciptakan daya tanggap diantara anggota, dan juga dalam upaya untuk meningkatkan keuntungan bersama. Nilai-nilai kepercayaan dan daya tanggap di antara anggota akan menimbulkan kerjasama dan solidaritas. Nilai kepercayaan diantara anggota dan keuntungan bersama akan menciptakan jaringan dan kebijakan. Sementara daya tanggap dan keuntungan bersama akan menciptakan persaingan dan keberlangsungan usaha. Kedua, terkait kekuatan norma (norm), kehidupan sosial masyarakat tradisional di Banaran dibatasi oleh norma-norma yang tersusun dalam suatu aturan adat tidak tertulis. Misalnya, norma-norma kebersamaan pada adat rewang dan sambatan di Desa Banaran mengikat kuat sehingga mampu menjadi benteng pertahanan yang menahan masuknya berbagai nilai-nilai baru yang tidak dikehendaki bersama (contohnya: sifat individualis). Ketiga, terkait kekuatan pekerja keras (hardworking) yang digambarakan dari keaktifan dalam organisasi kemasyarakatan dan keagamaan yang bertujuan untuk perbaikan dan kemajuan secara kolektif. Hasil penelitian menunjukkan bahwa rata-rata frekuensi pertemuan warga Desa Banaran adalah satu minggu sekali. Frekuensi pertemuan yang cenderung rutin ini mengindikasikan bahwa modal sosial yang ada ini sebenarnya merupakan modal yang kuat bagi masyarakat pedesaan sebagai bentuk kepercayaan dan tingginya hardworking diantara warga desa. Keempat, terkait jaringan kerja (networking) yang ditunjukkan pada kebutuhan masyarakat terhadap jaringan kerja formal (organisasi) dan informal (teman dekat). Ketergantungan masyarakat di Desa Banaran terhadap satu organisasi, nampak dalam kehidupan bermasyarakatnya yang ditunjukkan oleh beragam jenis organisasi terpenting bagi kehidupannya. Sehingga, sebagian besar masyarakat

Website: http://jurnal.radenfatah..ac.id/index.php/ieconomics 
I-Economic: A Research Journal on Islamic Economics

ISSN 2548-5601, e-ISSN 2548-561X

Vol 6. No 1. Juni 2020

perdesaan menyatakan bahwa organisasi tradisional merupakan kelompok terpenting yang berkaitan langsung dengan tingkat kesejahteraannya.

Strategi perumusan desain model agunan alternatif berbasis modal sosial sebagai upaya membangkitkan kembali sektor pertanian dan UMKM pada masyarakat daerah pasca bencana di Desa Banaran adalah dengan memberikan terobosan terkait revitaslisasi keuangan melalui agunan alternatif (pembiayaan berbasis modal sosial) baik yang disalurkan oleh lembaga keuangan formal dan non formal, lembaga keuangan bank dan non bank, serta lembaga keuangan umat (lembaga zakat dan wakaf). Adapaun karakteristik model pembiayaan ini antara lain: nasabah hanya terbatas pada masyarakat pedesaan atau pelosok, pembiayaan diberikan kepada kelompok, bukan perorangan, sumber modal berupa donasi, bukan investasi, pembiayaan bersifat produktif dan terdapat pembinaan usaha bagi nasabah, margin atau bagi hasil yang sangat rendah, dan nasabah tidak dibatasi oleh agama.

\section{DAFTAR PUSTAKA}

Al Thoyaar, Abdullah bin Muhammad. Al Fiqh Al Muyassarah, Qismul Mu'amalah Cet.I. Madara, $1425 \mathrm{H}$.

Azwar S. Sikap Manusia Teori dan Pengukurannya. Yogyakarta: Pustaka Pelajar, 2005.

Badan Pusat Statistik Kabupaten Ponorogo. Kecamatan Pulung dalam Angka: Tahun 2019. Ponorogo: BPS Kabupaten Ponorogo, 2019.

Badan Pusat Statistik Kabupaten Ponorogo. Kecamatan Pulung dalam Angka: Tahun 2016. Ponorogo: BPS Kabupaten Ponorogo, 2016.

Bogdan, Robert \& Steven J. Taylor. Introduction to Qualitative Research Methods: A Phenomenological Aprroach to The Social Sciences. New York: John Wiley \& Sons, 1975.

Bourdieu, Pierre. "The Form of Capita"dalam J. Richardons, Handbook of Theory and Research for The Sociology of Educations. Westport: Greenwood Press, 1986.

Bourdieu, Pierre. The Form of Capita"dalam J. Richardons, Handbook of Theory and Research for The Sociology of Educations. Westport: Greenwood Press, 1986.

Cahyono, Budhi. "Peran Modal Sosial dalam Peningkatan Kesejahteraan Masyarakat Petani Tembakau di Kabupaten Wonosobo. Jurnal Ekobis Vol. 15, No. 1 Januari 2014. Semarang: Unissula, 2014.

Coleman JS. Social Capital in The Creation of Human Capital. American Journal of Sociology, Vol. 94, 1988.

Daryanto, Arief. "Penguatan Kelembagaan Sosial Ekonomi Masyarakat Sebagai Modal Sosial Pembangunan. Jurnal Agrimedia. Volume 9, No.01, Maret 2004. Bogor: IPB, 2004.

Dasgupta dan Serageldin. Social Capital: A Multi Faceted Perspective. Washington DC: World Bank. 2002.

Website: http://jurnal.radenfatah..ac.id/index.php/ieconomics 
I-Economic: A Research Journal on Islamic Economics

ISSN 2548-5601, e-ISSN 2548-561X

Vol 6. No 1. Juni 2020

Fukuyama, Francis. Trust: The Social Virtues and The Craetion of Prosperity. New York: The Free Press, 1995.

Granovetter MS. The Strenght of Weak Ties. American Journal of Sociology, 78, 1360-80, 1973.

Hamid, M. Arifin. Hukum Ekonomi Islam (Ekonomi Syariah) di Indonesia Aplikasi dan Perspektifnya. Bogor: Ghalia Indonesia, 2007.

Hermawati, Mefi. Laporan Need Assesment Pengembangan Modal Sosial Masyarakat Adat. Yogyakarta: IRE, 2002.

Hernoko, Agus Yudha. Asas Proporsionalitas Dalam Kontrak Komersial. Yogyakarta: LaksBang Mediatama, Yogyakarta 2008.

Kharofa, Ala' Eddin. Transactions in Islamic Law. Kuala Lumpur: A.S. Noordeen, 1997.

Levi M. Social And Unsocial Capital: A Review Essay Of Robert Putnam's. Making Democracy Work, Politics and Society. 24 (March), 1996.

Lindon J, Robinson, Marcelo E. Siles, dan A. Alam Schmid. Social Capital and Proverty Reduction: Toward a Mature Paradigm. Departement of Agricultural economics, Michigan State University: Research Report, No. 13/2002.

Miles, Mathew B. dan A. Michael Huberman. Analisis Data Kualitatif: Buku Sumber tentang Metode-metode Baru, terj Tjetjep Rohendi Rohidi. Jakarta: UI Press, 1992.

Moleong, Lexy J. Metodologi Penelitian Kualitatif. Bandung: Remaja Rosdakarya, 2007.

Mosca dalam Olson M. The Rise and Decline of Nation. New Haven: Yale University Press, 1982.

Mulyana, Dedi. Metodologi Penelitian Kualitatif: Paradigma Baru Ilmu Komunikasi dan Ilmu Sosial Lainnya. Bandung: PT Remaja Rosdakarya, 2004.

Nourmanaf, A. Rozy. Lembaga Informal Pembiayaan Mikro Lebih Dekat dengan Petani, Ejournal Analsis Kebijakan Petanian 2007, pada pse.litbang.pertanian.qo.id, diakses 1 April 2017 pukul 03.20 WIB.

Pantoja E. Exporing the Concept of Social Capital and Its Relevancy for Community Based Development: The Case of Mining Areas in orissa, India. South Asia Infrastucture Unit: The World Bank, 1999.

Putman, Rober, Robert Leonardi dan RafellaNanetti. Making Democracy Work: Civic traditions in Modern Italy. Princeton: N.J: Princeton University Press, 1993.

Robinson G. The Dark side of Paradise: Political Violence in Bali. New York: Cornel University Press, 1995.

S. Nasution. Metode Penelitian Naturalistik Kualitatif. Bandung: Transito, 1996.

Sugiyono. Meahami Metode Penelitian Kualitatif. Bandung: Alphabeta, 2005.

Sujana, Nana dan Ahwal Kusuma. Proposal Penelitian di Perguruan Tinggi. Bandung: Sinar Baru Algesindo, 2000.

Supriatna, Ade. Pola Pelayanan Pembiayaan Sistem Kredit Mikro Usaha Tani di Tingkat Pedesaan, Jurnal Litbang Pertanian 28 (3). Bogor: Balai Besar Pengkajian dan Pengembangan Teknologi Pertanian, 2009.

Syafei, Rachmat. Fiqh Muamalah. Bandung: Pustaka Setia, 2000.

Website: http://jurnal.radenfatah..ac.id/index.php/ieconomics 